\title{
THE EFFECT OF LOKALATE PRODUCT QUALITY ON THE CUSTOMER LOYALTY THROUGH BONUS PACK PROMOTION IN JAMBI CITY
}

\author{
Dara Sonia ${ }^{1)}$, Syahmardi Yacob ${ }^{2)}$, Musnaini ${ }^{3)}$ \\ 1,2,3) Faculty of Economics and Business, Universitas Jambi, Jambi, Indonesia \\ Corresponding author: dara.sonia09@gmail.com
}

\begin{abstract}
The research purpose is to examine the effect of Local Product Quality on Customer Loyalty through Bonus Pack Promotion at Jambi City. Delivery questionnaires with several 125 respondents carried out the data collection. The data testing techniques used validity and reliability tests, R-square tests, and hypothesis testing - the research finds that Local Product Quality has a positive and significant effect on Customer Loyalty. Local Product Quality has a positive and significant impact on Bonus Pack Promotion. Moreover, Bonus Pack Promotion has a positive and significant impact on Customer Loyalty. However, Local Product Quality on the Customer Loyalty through Bonus Pack Promotion has no effect.
\end{abstract}

Keywords: Product Quality, Bonus Pack Promotion, Customer Loyalty

\section{Introduction}

The development of the business world in Indonesia is currently running rapidly, which creates increasingly fierce competition, including the coffee industry. A study conducted by Food and Agriculture Organization (FAOSTAT, 2016) stated that Indonesia was the fourth largest coffee-producing country in the world in 2015. Indonesian coffee has quality and taste that can compete, namely having high quality, specific taste, and various varieties. The superiority of Indonesian coffee that is maintained in quality makes coffee production in Indonesia from year to year continue to increase; the following data evidence this:

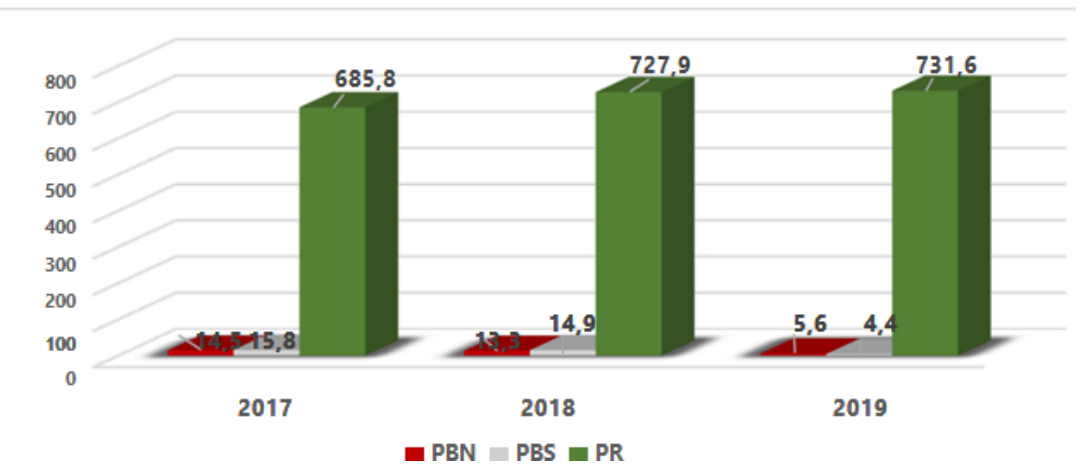

Source: Central Bureau of Statistics (Indonesian Coffee Statistics 2019)

Figure 1. Coffee Production in Indonesia in 2017-2019 (000 Tons)

Based on the coffee production data above shows that there was a fluctuating increase in coffee production in Indonesia from 2017 to 2019. Production in 2017 reached 685.80 thousand tons, then in 2018, it increased to 727.9 thousand tons and reached 731.6 thousand tons in 2019. This means that the coffee business in Indonesia has a broader market share which results in coffee production increasing every year. The domestic coffee industry relies on primary commodities alone (in coffee beans) and in processed forms to obtain a value that will increase domestic consumption. One of them is by verifying processed coffee, such as roasted coffee, coffee mix, decaffeinated coffee, soluble coffee, beer coffee (coffee beer), iced coffee, and instant coffee, which can become a leading commodity, with the combination of raw materials and suitable processing methods, it will produce maximum physical quality and taste of coffee (Pudji raharjo, 2012).

Product quality needs to get the company's immediate attention, considering that product quality is one of the means of positioning significant marketers. Kotler \& Amstrong (2012) stated that product quality is the characteristic of a product or service that bears on its ability to satisfy expressed or implied customer needs, which means that product quality is a characteristic of a product or service that provides the ability to meet customer needs.

PT. Nutrifood Indonesia (NFI) is a national private company engaged in the food and beverage industry, especially food and beverages that provide benefits for freshness, health, and appearance of international quality. PT Nutrifood Indonesia (NFI) has company area offices spread across almost all parts of Indonesia. One of which is in Jambi city, located at Abdurahman Saleh street, paal Merah City, Jambi. This company produces two kinds of products, namely diet and non-diet products. One of the non-diet products is Lokalate 
coffee. Lokale is a coffee powder drink with fruit and exotic local Indonesian spices. Lokale under the W'DANK brand is a contemporary coffee with a significant taste and uniqueness compared to other coffees. Lokale comes in various varieties, including kawista coffee, avocado coffee, palm sugar coffee, durian coffee, popsicle coffee, sticky tape coffee, and andaliman coffee. With this variety of flavors, Lokalate coffee has a unique characteristic with a competitive taste to compete in the market.

In maintaining the company's survival, one way that the company must do is to maintain customer loyalty. Customer loyalty is essential because if the company can maintain customer loyalty, it can be a precious asset. Kotler \& Keller (2016) mention that customer loyalty is those who repeatedly go to the same place to satisfy wants by getting and paying for products or services. Customer loyalty can be maintained by employing sales promotions. Sales promotion is one of the most critical strategic components in the marketing mix. There is four promotion mix according to Kotler (2008), namely Advertising (Advertising), Sales promotion (Sales Promotion), Personal Selling (Personal Selling), and Publicity (Public Relations). According to Kotler and Armstrong in Foster (2008), the purpose of using sales promotion is to increase customer loyalty. In conducting sales promotions, companies can do several types of promotions. According to Ma'ruf (2006), one of the sales promotions that can be done is by providing bonus packs. A bonus pack is an extra charge of a product at a standard price (Belch and Belch in Saputra, (2019). Since the product content is added and there is no extra charge, customers will find it more profitable to buy the product if they feel they are getting more significant value than the money they spend. Based on the above background causes researchers to want to know the effect of product quality on customer loyalty mediated by bonus pack promotion, so this research is entitled "The Effect Of Lokalate Product Quality On The Customer Loyalty Through Bonus Pack Promotion In Jambi City."

Formulation of the problem:

1. Does Lokalate's product quality affect customer loyalty in Jambi City?

2. Does the quality of Lokalate products affect the bonus pack promotions in Jambi City?

3. Does bonus pack promotion affect customer loyalty in Jambi City?

4. Does Lokalate's product quality affect customer loyalty through bonus pack promotion in Jambi City?

\section{Research purposes}

The purpose of this research are:

1. To explain the effect of Lokalate product quality on customer loyalty in Jambi City

2. To explain the effect of Lokalate product quality on bonus pack promotion in Jambi City

3. To explain the effect of bonus pack promotion on customer loyalty in Jambi City

4. To explain the effect of Lokalate product quality on customer loyalty through bonus pack promotion in Jambi City

\section{Literature Review \\ Marketing}

Marketing is one of the most essential activities in a company. The meaning of marketing, according to The America Marketing Association in Gundlach \& Wilkie (2009), is an organizational function and a set of processes for creating, communicating, and delivering value to customers and its stakeholders, which means that marketing is an organizational function and a bunch of processes for creating, communicating and delivering value to customers and managing customer relationships in ways that benefit the organization and its stakeholders (Kotler \& Keller, 2006). Marketing, according to Kotler and Keller (2009), is the art of selling products or services the art of selling products; thus, marketing management is the art and science of choosing target markets and gaining, retaining, and growing customers by creating, delivering, and communicating superior customer value

\section{Product Quality}

Product quality is critical in a business. Lupiyoadi and Hamdani (2009) state that quality is a combination of traits and characteristics that determine how the output can meet customer needs. According to Deming in a book by MN Nasution (2001) entitled Integrated Quality Management Total Quality Management, quality is conformance to market or consumer needs.

Product Quality Dimension according to Orville, Larreche, and Boyde (2005), if the company wants to maintain its competitive advantage in the market, the company must understand what dimensions are used by consumers to differentiate the products sold by the company from competitors' products. Product Quality dimensions include:

1. Performance relates to the essential operating characteristics of a product

2. Durability, how long the product's life will last before the product must be replaced.

3. Conformance to Specifications, namely the extent to which the essential operating characteristics of a product meet certain specifications from consumers.

4. Features are product characteristics designed to enhance product functionality or increase consumer interest. 
5. Reliability is the probability that the product will perform satisfactorily or not within a certain period.

6. Aesthetics relates to how the product's appearance can be seen from the appearance, taste, and shape.

7. Perceived quality is the result of using indirect measurements because there is a possibility that consumers do not understand the information on the product in question.

\section{Bonus Pack Promotion}

Clow and Back (2012) stated that when an additional or an extra number of items are placed in a particular product package, it is a bonus pack. When any number of items is added to a specific product package, it is a package bonus. According to Belch \& Belch (2012), a bonus pack offers consumers an extra charge of a product at a standard price. According to Mishra \& Mishra (2011), a bonus pack is a quantitybased sales promotion strategy in which customers are offered more products at the same price.

Indicator Bonus Pack, according to Belch \& Belch (2012), mention indicators of a bonus pack, that are:

1. Provide offers with extra benefits.

2. Strategy to survive the promotion of new products from competitors.

3. Generate larger sales orders.

\section{Customer loyalty}

Customer loyalty is an important goal in a company. Kotler and Keller (2012) state that customer loyalty is a situation where customers consistently spend the entire existing budget to buy a product or service from the same seller. In general, it can be interpreted as a person's loyalty to a product, either goods or services served by a company or store (Burju Sihombing et al., 2017). Customer loyalty is a customer's commitment to a store brand or supplier, based on a very positive attitude, and is reflected in consistent repeat purchases (Morais in Sangadji and Copiah 2013).

Customer Loyalty Dimension according to Griffin (2009), Loyal customers are customers who have the following characteristics/dimensions:

1. Make regular repeat purchases

2. Buying outside the product/service line

3. Referring shop to others

4. Demonstrate immunity to attractiveness from competitors

\section{Framework}

Based on the previous explanation, it can be described the framework of thinking as follows:

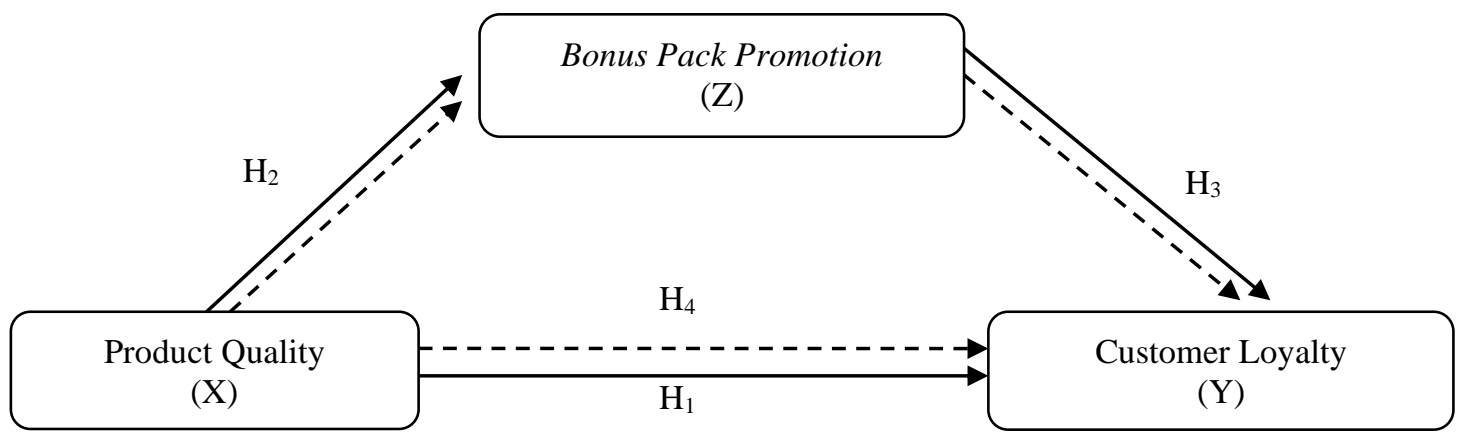

Figure 2. Framework

\section{Hypothesis:}

H1: Lokalate product quality affects customer loyalty in Jambi City

$\mathrm{H} 2$ : Lokalate product quality effects Bonus pack promotion in Jambi City

H3: Bonus pack promotion affect customer loyalty in Jambi City

H4: Lokalate product quality affects customer loyalty through bonus pack promotion in Jambi city

\section{Research Methods \\ Research Approach}

In this study, the approach used by the researcher is quantitative research using statistical formulas to help analyze the data and facts obtained. Sugiyono (2017) states that quantitative research methods are defined as research methods based on the philosophy of positivism used to examine specific populations or samples. Hermawan \& Amirullah (2016) stated that the quantitative approach is research whose analysis emphasizes numerical data (numbers) processed using statistical methods.

\section{Data Types and Sources}

The type of research used in this research is descriptive research with a quantitative approach. Descriptive research is a method that is researched through data that has been collected as it is (Sugiyono, 2016). The 
questionnaires collect data to test hypotheses or answer a question/statement. In this study, researchers used primary data in a closed questionnaire. Respondents choose the answer by giving a checklist on the appropriate response according to the respondent. Deployment The questionnaire was carried out with the technique of snowball sampling. According to Sugiyono (2014), snowball sampling is a technique for determining samples that are initially small in number and then enlarged. In this study, the researchers also used data on coffee production in Indonesia in 2019. The source of this data was obtained indirectly through intermediary media, which are complementary. Secondary data in this study were also obtained from various library materials in journals, books, electronic data that the researchers took via the internet.

\section{Method of collecting data}

The data collection method is the most strategic step in research. Because the primary purpose of a study is to get data (Sugiyono, 2017). In this study, researchers conducted data collection techniques using a questionnaire. This research questionnaire was distributed online to respondents in a Google form and disseminated on social media. To measure the above variables used a Likert Scale of 5 (five) levels as follows: STS (1), TS (2), N (3), S (4), and SS (5).

\section{Population and Sample}

In this study, all people have consumed or purchased Lokalate coffee products at least once or more. This population is based on the number of consumers who are not known in number or unlimited. The sampling technique in this study used purposive sampling. The criteria for the sample selected as respondents are consumers who have consumed Lokalate coffee or bought Lokalate coffee products. Determination of the sample using a conventional approach, according to Malhotra (2007), for a survey with an unknown population and the unit of analysis is the consumer, the number of samples or respondents with a total population is 100-125 respondents. Researchers used 125 respondents as samples; the respondents taken in this study were people who had consumed or bought Lokalate coffee products at least once or twice.

\section{Variable Operation}

The following are operational variables designed for questionnaires in research.

1. Product Quality is the ability of a product to perform various functions, including durability, reliability, accuracy, and ease of use (Kotler and Armstrong, 2008: 213). According to Orville, Larreche, and Boyde (2005), the dimensions of product quality are as follows: Durability, conformance to Ingredients, Aesthetics, Perceived Quality

2. Bonus packs are a quantity-based sales promotion strategy where customers are offered more products at the same price (Mishra \& Mishra, 2011). According to Belch \& Belch (2012), there are three bonus pack indicators: Providing offers with extra benefits, Strategies to defend against products from competitors, Generating larger sales order

3. Customer loyalty, in general, can be interpreted as a person's loyalty to a product, both goods or services served by a company or store (Burju Sihombing et al., 2017). According to Griffin (2009) states, there are several dimensions of customer loyalty, including Make regular repeat purchases, buying outside the product/service line, Referring products to others, which means attracting new customers to the company (other references), Not easily attracted by competitor's products

\section{Analysis Tools}

Data processing in this study was carried out by processing the data from the sample answers through a questionnaire. The analytical tool used in this research is PLS (Partial Least Square). The method used to determine the condition of "The Influence of Local Product Quality on Customer Loyalty through bonus Pack Promotion" needs to do coding on each indicator. The indicator used to describe " The Effect Of Lokalate Product Quality On The Customer Loyalty Through Bonus Pack Promotion In Jambi City." Analysis of the data in this study using the approach Partial Least Square (PLS) by using software Smartpls 3 PLS.

Wiyono (2011) states that PLS is an analytical method that powerful because it can be applied to all data scales, does not require many assumptions, and the sample size does not have to be significant.

\section{Result and Discussion Characteristics of Respondents}

Respondents in this study were all Jambi City who had consumed Lokalate coffee at least once or more. Respondents in this study amounted to 125 people. In this study, respondents were classified according to several categories based on gender, divided into male and female. Based on the respondent's data, the analysis results were $72.8 \%$ female respondents, while male respondents were $27.2 \%$. Second, based on age, most respondents are aged $15-25$ years, about $98.4 \%$ of the total respondents, illustrating that on average, the respondents are still classified as productive age. Third, based on the number of product consumption, respondents who dominate have consumed Lokalate products one time (one time) with a percentage of $53.6 \%$. Respondents with consumption intensity more than $1 \mathrm{x}$ have a ratio of $46.4 \%$. Fourth, based on the 
latest education, the percentage level based on the last education is High School Graduation/Equivalent by 59.2\%, Undergraduate 38.4\%, Post Graduate 1.6\% and Elementary School Graduation 0.8\%. Respondents who have consumed Lokalate at least once or more are dominated by people with the last education graduating from high school/equivalent.

\section{R-Square}

Table 1. R-Square Value

\begin{tabular}{lc}
\hline \multicolumn{1}{c}{ Variable } & R Square \\
\hline Bonus Pack Promotion $(\mathrm{Z})$ & 0,310 \\
\hline Customer Loyalty $(\mathrm{Y})$ & 0,472 \\
\hline Source: Results of Primary Data Processing by Researchers (November 2021)
\end{tabular}

Based on Table 1, showing the results for the R-square value of 0.310 , it can be interpreted that the variable bonus pack promotion, which the product quality variable can explain, is $31 \%$, the remaining $69 \%$ is explained by other variables not examined. While the R-square value of 0.472 can be interpreted that the variability of the customer loyalty constructs, which can be explained by the variability of the product quality construct and bonus pack promotion, is $47.2 \%$. The remaining $52.8 \%$ is explained by other variables outside the study.

\section{Discriminant Validity}

The following is the Average value Variance Extracted (AVE), Composite Reliability, Cronbach Alpha of the variables used in this study:

Table 2. Construct Reliability and Validity

\begin{tabular}{lccc}
\hline \multicolumn{1}{c}{ Variable } & $\begin{array}{l}\text { Average Variance } \\
\text { Extracted (AVE) }\end{array}$ & $\begin{array}{l}\text { Composite } \\
\text { Reliability }\end{array}$ & Cronbach Alpha \\
\hline Product Quality (X) & 0,635 & 0,933 & 0,917 \\
\hline Bonus Pack Promotion (Z) & 0,680 & 0,927 & 0,906 \\
\hline Customer Loyalty (Y) & 0,657 & 0,939 & 0,925 \\
\hline $\mathrm{X} * \mathrm{Z} * \mathrm{Y}$ & 1,000 & 1,000 & 1,000 \\
\hline
\end{tabular}

Source: Results of Primary Data Processing by Researchers (November 2021)

Based on table 2, the AVE value shows that it is above 0.50, which means that all constructs in the estimated model have good discriminant validity. In addition, it can be concluded that all constructs have reliable criteria. This is indicated by the value of composite reliability above 0.70 and the value of Cronbach alpha, which is good, is $>0.7$.

\section{Hypothesis Test}

Table 3. Result for Inner Weights

\begin{tabular}{lccccc}
\multicolumn{5}{c}{ Table 3. Result for Inner Weights } \\
\hline & $\begin{array}{c}\text { Original } \\
\text { Sample } \\
\text { Estimate }\end{array}$ & $\begin{array}{c}\text { Sample } \\
\text { Mean } \\
\text { (M) }\end{array}$ & $\begin{array}{c}\text { Standard } \\
\text { Deviation }\end{array}$ & $\begin{array}{c}\text { T } \\
\text { Statistics }\end{array}$ & P Values \\
\hline $\begin{array}{l}\text { Product Quality (X) -> Customer Loyalty } \\
\text { (Y) }\end{array}$ & 0,595 & 0,608 & 0,110 & 5,422 & 0,000 \\
\hline $\begin{array}{l}\text { Product Quality (X) -> Bonus Pack } \\
\text { Promotion (Z) }\end{array}$ & 0,557 & 0,563 & 0,084 & 6,603 & 0,000 \\
\hline $\begin{array}{l}\text { Bonus Pack Promotion (Z) -> Customer } \\
\text { Loyalty (Y) }\end{array}$ & 0,225 & 0,218 & 0,110 & 2,056 & 0,040 \\
\hline $\begin{array}{l}\text { Product Quality on Customer Loyalty } \\
\text { through Bonus Pack Promotion (X*Z*Y) }\end{array}$ & 0,054 & 0,053 & 0,042 & 1,306 & 0,192 \\
\hline
\end{tabular}

Source: Results of Primary Data Processing by Researchers (November 2021)

In using PLS, statistical testing of each hypothesized relationship is carried out using simulation; in this case, the method is used Bootstrap against samples; testing with Bootstrap is also intended to minimize the problem of abnormal research data. Test results with bootstrapping from the PLS analysis are as follows:

1. The effect of Lokalate Product Quality on Customer Loyalty

Based on the results of hypothesis testing, it is known that the t-statistic value is 5.422. Thus this result follows the rule of thumb, which t-statistic $>1.96$. It can be stated that product quality directly affects customer loyalty by $54.2 \%$, which means that hypothesis 1 , which reads that local product quality affects customer loyalty in Jambi City, is accepted. 
2. The effect of Lokalate Product Quality on Bonus Pack Promotion

Based on the results of hypothesis testing, it is known that the $t$-statistic value is 6.603. Thus, this result follows the rule of thumb, which t-statistic > 1.96. It can be stated that the effect of Product Quality has a direct positive impact on Bonus Pack Promotion by 66\%, which means that hypothesis 2, which reads that the Lokalate Product Quality affects Bonus Pack Promotion in Jambi City, accepted.

3. The effect of Bonus Pack Promotion on Customer Loyalty

Based on the results of hypothesis testing, it is known that the t-statistic value is 2.056 . Thus, these results indicate that Bonus Pack Promotion directly affects Customer Loyalty of $20.56 \%$, which is t-statistic > 1.96. Based on this description, hypothesis 3, which reads Bonus Pack Promotion affects Customer Loyalty in Jambi City, accepted.

4. The effect of Lokalate Product Quality on Customer Loyalty Through Bonus Pack Promotion

Based on the results of hypothesis testing, it is known that the t-statistic value is 1.306 . Thus, this result is not following the rule of thumb, $\mathrm{t}$-statistic $<1.96$. Based on these results, it can be stated that Product Quality on Customer Loyalty Through Bonus Pack Promotion has no effect. In the sense, bonus pack promotion as an intervening variable is not a determining variable in maintaining and increasing customer loyalty. This means that hypothesis 4, which reads that Lokalate Product Quality Affects Customer Loyalty through Bonus Pack Promotion in Jambi City, is rejected.

\section{Discussion \\ The Effect of Lokalate Product Quality on Customer Loyalty}

The study results indicate that the quality of Lokalate products has a direct positive effect on customer loyalty, meaning that the quality of lokalate products has met customer expectations and desires, both in terms of durability, which includes expiration and durability. Packaging, conformity with ingredients, which includes product composition and unique taste variants, aesthetics, the beauty of the packaging, and the impression of quality, namely consumer perceptions of the Lokalate product. This is based on research data that shows that Lokalate products' quality affects $54.2 \%$ of loyalty customers. It can be interpreted, so far Lokalate products have had a good position in the perception of consumers or customers. Lokalate products have succeeded in providing and maintaining the aesthetics of their packaging, product durability, a unique taste that is constantly innovated so that consumers do not get bored quickly and do not switch to competing products. This can also be interpreted that maintaining good product quality is an essential fundamental thing that will impact the company's survival because product quality is one of the factors to maintain customer loyalty. This is indeed the hope that every company wants to optimize profits. Will be obtained. So, it can be concluded that the more maintained the quality of a product, the more customer loyalty will be held.

This study is also positively correlated with previous research conducted by Lestari \& Yulianto (2018), saying that product quality variables have a positive effect on customer loyalty, as well as Cahyati's research (2018) also shows the same results, namely product quality variables has a direct impact on the variable of customer loyalty. With the existence of several previous studies prove that product quality is an essential factor that can maintain and even increase customer loyalty.

\section{The Effect of Lokalate Product Quality on Bonus Pack Promotion}

The results showed that the quality of Lokalate products had a direct positive effect on bonus pack promotion which is realized in the form of buy two get one free of $66 \%$. This means that Lokalate coffee products with the best quality can influence sales promotions so that sales promotions are in the form of the bonus pack was successfully realized. It can also be interpreted that good product quality becomes a determinant in increasing the probability of successful sales promotions in sales promotions bonus packs. It can also be interpreted that product quality is a determinant or positive force in driving the success of sales promotions in the form of bonus packs. This also means that one of the success factors of sales promotion in a bonus pack is to maintain good product quality. Thus consumers or customers will not feel disappointed with the products they buy. In research on bonus pack promotion, consumers or customers benefit more by getting different products free without additional costs. Thus, the company must maintain a sense of pleasure or satisfaction of its customers while still paying attention to the quality of the products marketed. Even though the company is providing promotion for the product, the company should not reduce the quality of the product so that it can harm or disappoint consumers. This is in line with the purpose of a sales promotion in the long term, namely to strengthen brand/product associations and awareness, strengthen product loyalty, and give the impression of the desired quality. With long-term goals, it is hoped that promotional actions can always influence consumers to use a product and not switch to similar products produced by competing companies (David Aaker 1997).

\section{The Effect Of Bonus Pack Promotion on Customer Loyalty}

The results of the study indicate the fact that bonus pack promotion has a direct positive effect on customer loyalty, meaning that sales promotions in the form of bonus packs have a strength that needs to be taken into account because it is based on the data of this study bonus pack promotion has a direct positive effect on customer loyalty by $20.56 \%$. This can also be interpreted that bonus pack promotion is an essential factor indirectly maintaining customer loyalty. A previous study conducted by Madekissa (2019) and Nabilah 
(2017) research showed positive results, and namely bonus pack affects impulse buying. The two studies above do not intersect with the customer loyalty variable or support this research. However, at the time of the initial survey, the author found that one of the factors a person is loyal to a product is the presence of bonus pack promotion. The results of this research data have successfully proved these assumptions. Although in previous studies, there were no studies that examined the relationship between variables bonus pack promotion on customer loyalty, according to Kotler and Armstrong in Foster (2008) explains that the purpose of using sales promotions is one of them to increase customer loyalty. There are four promotional mixes, according to Kotler (2008), namely Advertising, Sales promotion, Personal Selling, and Publicity. This study means a positive correlation with the expert's statement that bonus pack promotion has a positive effect on customer loyalty; in other words, sales promotions carried out in the form of bonus packs can maintain or increase customer loyalty.

\section{The Effect of Lokalate Product Quality on Customer Loyalty Through Bonus Pack Promotion}

The results of this study indicate that the effect of Lokalate product quality on customer loyalty through Bonus Pack Promotion has no effect; it means variable bonus pack promotion as an intervention between product quality and customer loyalty has a weak role can be said to have no effect. It can also be interpreted that the variable bonus pack promotion in mediating product quality on customer loyalty is not a determining variable; variable bonus pack promotion is not determinant in increasing customer loyalty. Without bonus pack promotion as an intervening variable, consumers or customers will remain loyal to the product because the product has good quality. Although the previous three hypotheses were accepted, the fourth hypothesis was rejected. Variable bonus pack promotion as an intervention or Product Quality affects Customer Loyalty through Bonus Pack Promotion. This is unacceptable. This means the intervening variable, which in this case is bonus pack promotion, does not have a significant role or needs to be taken into account to maintain customer loyalty because customer loyalty itself can be maintained and improved with good product quality without the need to be mediated by variables bonus pack promotion as the intervention. In a previous study, Rahman et al. (2020) showed the fact that Bonus Pack positive effect on Purchase Intention. Previous research did not find research related to Product Quality variables on Customer Loyalty through Bonus Pack Promotion. However, companies must still have a strategy to survive competitors in the business world. Mary Pezullo. (1999), in the book Marketing For Banking, American Bankers Association, stated that one of the strategies defensive (survive), is a step taken with a promotional strategy whose goal is that consumers or customers do not forget the brand of a product or turn to other brands or products.

\section{Conclusion}

Based on the results of the analysis of the effect of Lokalate Product Quality on Customer Loyalty through Bonus pack Promotion In Jambi City, the conclusions are: Product quality is an important variable that can play a role in maintaining and increasing customer loyalty to a product; Product quality is a variable that will determine the success of sales promotions in the form of bonus pack (bonus pack promotion); Bonus pack promotion is a sales promotion that can maintain and increase customer loyalty for Lokalate products in Jambi City; Bonus pack promotion has a significant role in customer loyalty directly, but if bonus pack promotion mediates between product quality and customer loyalty, the position has no effect.

\section{Suggestion}

Based on the results of the research conducted, the following suggestions can be given; For practitioners/business actors, it is hoped that the company will continue to improve the quality of existing products and carry out sales promotions, namely: bonus pack promotion, to maintain and increase customer loyalty. This is done by continuously providing the latest innovations, as well as improving the quality of Lokalate products and methods of realizing their sales promotions, increasing their advantages such as adding unique flavors that are in line with market demands, maintaining packaging aesthetics so that it has an ergonomic value, providing bonus pack promotion at the right time to consumers while maintaining the quality of their products so that consumers feel happy and make the product as one of the top minds in their perception. Thus consumers are also pleased to recommend the product to expand market share; The government/public is expected to continue to support local or domestic products to develop more rapidly and be increasingly recognized by the people, both nationally and internationally; Academics are expected to contribute to the development of marketing strategies by looking at product quality, bonus pack promotion, customer loyalty.

\section{References}

Annishia, F. B., \& Setiawan, M. S. (2018). Pengaruh Kualitas Produk Kopi Terhadap Kepuasan Konsumen Di Jade Lounge Swiss- Belresidences Kalibata Jakarta Effect Of Quality Of Coffee Products On Customer Satisfaction In Jade Lounge Swiss-Bel Residences Kalibata Jakarta. 4(1), 60-69. 
Brian Vicky Prihastama. (2016). Pengaruh Price Discount Dan Bonus Pack Terhadap Impulse Buying Pada Pelanggan Minimarket. 05(02), 170-188.

Burju Sihombing, R., Hendrawan, H., \& Mujianto, H. (2017). Jurnal Komunikasi Hasil Pemikiran Dan Penelitian-P-Issn: 2461-0836 E-Issn: 2580-538x 2017. 3, 87-101.

Cahyati, D. N. (2018). Pengaruh Kualitas Produk Dan Brand Image Terhadap Loyalitas Pelanggan Dengan Kepuasan Konsumen Sebagai Variabel Intervening (Studi Pada Konsumen Produk Buccheri Di Kota Kediri). Http://Etheses.Uin-Malang.Ac.Id/13770/

Carlson, J. P., Weathers, D., \& Swain, S. D. (2016). Consumer Responses To Bonus Pack And Product Enlargement Claims. 24(1), 59-71. Https://Doi.Org/10.1080/10696679.2016.1089764

Faostat. (2016). Food And Agriculture Data 2016. Rome: Food Agric. Organ.

Gundlach, G. T., \& Wilkie, W. L. (2009). The American Marketing Association ' S New Definition Of Marketing : Perspective And Commentary On The 2007 Revision. 9156, 259-265.

Hutomo, A., Marditama, T., Limakrisna, N., Sentosa, I., Lee, J., \& Yew, K. (2020). Green Human Resource Management, Customer Environmental Collaboration And The Enablers of Green Employee Empowerment: Enhancing An Environmental Performance. 1(2), 358-372. Https://Doi.Org/10.38035/Dijefa

Isfantin, S., \& Lestari, P. (2018). Pengaruh Price Discount Dan Bonus Pack Terhadap Impulse Buying Melalui Nilai Hedonik Di Carrefour Surakarta. 7(2), 129-140. Https://Doi.Org/10.30588/Jmp.V7i2.362

Kotler \& Amstrong. (2012). Manajemen Pemasaran. Kotler Amstrong 2012.

Kotler, P., \& Keller, K. L. (2016). Markkotler, P., \& Keller, K. L. (2016). Marketing Management. Global Edition (Vol. 15e). Https://Doi.Org/10.1080/08911760903022556eting Management. In Global Edition.

Lamuna, P., \& Bone, K. (2019). Jurnal Organisasi Dan Manajemen. 1(1).

Lestari, A., \& Yulianto, E. (2018). Pengaruh Kualitas Produk Terhadap Loyalitas Pelanggan Dengan Kepuasan Pelanggan Sebagai Variabel Mediasi (Survei Pada Pelanggan Citra Kendedes Cake \& Bakery J1 . S . Hatta B3 Kav. A, Kota Malang). Jurnal Administrasi Bisnis (Jab), 54(1), 74-81.

Lim, S., Cha, O., Korea, S., Choi, I., Korea, S., Lim, S., Cha, O., \& Puntoni, S. (2016). Association For Consumer Research. 44.

Madekissa, I. H. (2019). View Metadata, Citation And Similar Papers At Core.Ac.Uk.

Mallon, J., Stevenson, V., \& Mackenzie, G. (2021). William Gilmore Stevenson (1943-2021). Journal Of The Royal Statistical Society: Series A (Statistics In Society). Https://Doi.Org/10.1111/Rssa.12726

Maria Santika, N., \& Suwardi. (2017). Pengaruh Bonus Pack, Daya Beli, Dan Kepercayaan Institusi Terhadap Loyalitas Pengguna E-Money Campuspay Fransiska Novita Maria Santika 1) , Suwardi 2) Program Studi Manajemen Fakultas Ekonomi Universitas Muhammadiya Semarang.

Nabilah. (2017). Analisis Pengaruh Diskon Harga, Bonus Pack Dan Pendapatan Konsumen Terhadap Keputusan Pembelian Impulsif Pada Konsumen Supermarket Carrefour Di Surakarta.

Ogbonnaya, C., Ogba, I., \& Emeka, E. (2020). Examining The Effect Of Customers 'Perception Of Bank Marketing Communication On Customer Loyalty. Scientific African, 8, E00383. Https://Doi.Org/10.1016/J.Sciaf.2020.E00383

Park, S., Park, H. S., Phuong, D. X., \& Kumar, S. (2019). Sciencedirect Sciencedirect Sciencedirect Ai Based Injection Molding Process For Consistent Product Quality Ai Based Injection Molding Process For Consistent Product Quality For Zanin Costing Models For Capacity Optimization In Industry 4 . 0 : Trade-Off. Procedia Manufacturing, 28, 102-106. Https://Doi.Org/10.1016/J.Promfg.2018.12.017

Prakoso, S. B. (2014). Semarang.

Rahman, S. H., Rohaeni, H., Wijaya, S., \& Dewi, K. (2020). Pengaruh Price Discount Dan Bonus Pack Terhadap Purchase Intention. 2(1), 24-36.

Saputra, R. (2019). Analisa Brand Melalui Penyelenggaraan Event Product Launching Explorer Dream Cruise. Journal Of Chemical Information And Modeling, 53(9), 1689-1699.

Setyasih, D. A. (2017). Analisis Pengaruh Price Discount, Bonus Pack, Dan In-Store Display Terhadap Keputusan Impulse Buying Behavior Konsumen.

Sundström, M., \& Hjelm-Lidholm, S. (2020). Re-Positioning Customer Loyalty In A Fast Moving Consumer Goods Market. 28, 30-34. Https://Doi.Org/10.1016/J.Ausmj.2019.09.004

Syazkia, S. N., Yuliati, A. L., Telkom, U., Discount, P., \& Buying, I. (2018). The Effect Of Bonus Pack And Price Discount On Impulse Global Retail Development Index 2017. 5(2), 2561-2568.

Tripp, C., Ho, F. N., \& Ong, B. S. (2016). Consumer Perceptions Of Bonus Packs : An Exploratory Analysis Journal Of Consumer Marketing Article Information: April 1997. Https://Doi.Org/10.1108/07363769710166747

Witcher, B. J. (2020). Pengaruh Experiental Marketing, Bonus Pack, Dan Brand Image Terhadap Customer Satisfaction Pada Matahari Department Store Matos Malang.

Kotler, P Dan K. L. Keller. 2009. Manajemen Pemasaran, Jilid 1, Edisi 13. Jakarta: Pt. Index

Lovelock, Christoper, Wirtz, J., \& Mussry, J. (2012). Pemasaran Jasa Manusia, Teknologi, Strategi: Perspeltif Indonesia. Jakarta: Erlangga.

Kotler, P., \& Armstrong, G. (2010). Principles Of Marketing. 13th Ed. New Jersey: Pearson Education, Inc. 
Assauri, S. 2009, Manajemen Pemasaran Konsep Dasar Dan Strategi. Edisi Pertama Penerbit. Pt. Raja Grafindo Persada. Jakarta. 